\title{
Can Ptilinopus greyii (Columbidae) Disperse Seeds in New Caledonia's Dry Forests?
}

\author{
Facques Tassin, ${ }^{2,3}$ Mélanie Boissenin, ${ }^{4}$ and Nicolas Barré 4,5
}

\begin{abstract}
Conservation of endangered habitats of South Pacific islands is partially dependent on activity of seed dispersers. In consuming fruits, animals can spread seeds from parent plants to distant sites, thus contributing to plant regeneration and colonization of new sites. In the dry forests of New Caledonia, the red-bellied fruit-dove, Ptilinopus greyii, is a potential disperser of many fleshyfruited species. Trials with a captive bird showed that gut passage enhanced seed germination for Diospyros fasciculosa and Mimusops elengi but not for Vitex cf. collina, compared with whole fruits. Gut passage did not shorten duration of seed dormancy, which is consistent with evidence of a simple deinhibition effect for D. fasciculosa and M. elengi. Minimum Retention Time (MRT) of seeds in the gut differed significantly between the three tree species, from a mean of $17.4 \mathrm{~min}$ for D. fasciculosa to a mean of $52.4 \mathrm{~min}$ for $M$. elengi. These times are longer than observed foraging times in fruiting trees, potentially making this fruit-dove an effective seed disperser.
\end{abstract}

TropiCAL DRY FORESTS are the most endangered ecosystems of New Caledonia (Gillespie and Jaffré 2003). As with many other endangered habitats of South Pacific islands, their conservation is partially dependent on the activity of seed dispersers (Cox et al. 1991, Carlquist 1996, Meehan et al. 2002, McConkey et al. 2004, Harbaugh and Baldwin 2007, Tassin et al. 2008). By consuming fruits, animals can spread the seeds from the parent plants to distant sites, thus contributing to plant regeneration and colonization

1 This study was funded by Caledonian Agronomy Institute and Dry Forest Programme (action 1.9., 2006). Manuscript accepted 15 January 2010.

${ }^{2}$ Centre de Coopération Internationale en Recherche Agronomique pour le Développement (CIRAD), Unité de Recherche (UR) 105, Campus International de Baillarguet, 34398 Montpellier Cedex 5, France. .fr).

${ }^{3}$ Corresponding author (e-mail: jacques.tassin@cirad

${ }^{4}$ Institut Agronomique néo-Calédonien (IAC), B.P. 73, 98890 Païta, New Caledonia.

${ }^{5}$ CIRAD, UR 22, Campus International de Baillarguet, 34398 Montpellier Cedex 5, France.

Pacific Science (2010), vol. 64, no. 4:527-532

doi: $10.2984 / 64.4 .527$

(C) 2010 by University of Hawai'i Press

All rights reserved of new sites (Willson and Traveset 2000). Information is still lacking on the precise role of seed-dispersing animals, such as identifying the plant species dispersed and the animals' effectiveness in their dispersal.

In New Caledonia, our knowledge of the role of birds in seed dispersal is still based essentially on unpublished observation. To our knowledge, the only New Caledonian dryforest species about which information has been published is sandalwood (Santalum austrocaledonicum) (Tassin et al. 2008). Broad programs to conserve the dry forests of the country are operating in the absence of efforts to understand and promote their regeneration. Yet, understanding and promoting plant regeneration are crucial to assure the long-term conservation of dry forests (Janzen 2002).

Germination enhancement has been considered to be one of the principal advantages of seed ingestion by frugivorous animals and may be a crucial component of disperser effectiveness (Van der Pijl 1982, Traveset et al. 2007). Ingestion of seeds by frugivorous birds can affect germination in two ways: (1) mechanical or chemical alteration of seed coat structure in the gut (scarification effect), and (2) removal of chemical compounds in the pulp that would inhibit germination if left 
in contact with seeds (deinhibition effect) (Mayer and Poljakoff-Mayber 1982, Agami and Waisel 1986, Traveset and Verdu 2001, Samuels and Levey 2005). Ideally, a study on the effects of gut passage on seed germination should disentangle deinhibition and scarification effects (Robertson et al. 2006, Traveset et al. 2007).

Ptilinopus is a fruit-dove genus (Columbidae) that occurs from Southeast Asia via Wallacea and the Philippines to Australia and the Pacific. This is a large genus with roughly 50 species and includes some extinct taxa (Brooke and Jones 1995, Steadman and Freifeld 1999, Brown and Hopkins 2002). Ptilinopus species are considered to be active dispersers of seeds from fleshy-fruited trees, including in the dry forests of New Caledonia. We surveyed the foraging behavior of birds on fruits of dry-forest trees; we observed that the red-bellied fruit-dove (Ptilinopus greyii Bonaparte) fed mainly on nine species (Boissenin et al. 2006).

In this paper, we explore the potential of the red-bellied fruit-dove to be a disseminator of seeds of Diospyros fasciculosa F. Muell., Mimusops elengi L., and Vitex cf. collina (Veillon 7016). We considered these species as plant models, locally common fleshy-fruited trees growing in the habitats and included in the nine species fed upon by $P$. greyii. Our objectives were to assess, for each of the three tree species, the effect of fruit ingestion by $P$. greyii on seed germination and the retention time during gut passage.

\section{MATERIALS AND METHODS}

Dry forests are found up to $300 \mathrm{~m}$ above sea level on the leeward side of New Caledonia, with rainfall not exceeding $1,100 \mathrm{~mm}$ per year (Gillespie and Jaffré 2003). They originally covered a land area of between 1,000 and $4,500 \mathrm{~km}^{2}$, but during the last three millennia human activities have reduced their total area to about $1 \%$ of the original cover. Their high level of fragmentation reduces gene fluxes, making long-distance seed dispersal (between fragments) crucial.

The red-bellied fruit-dove is a forest bird species widely distributed in both New Cale- donia and Vanuatu (Gibbs et al. 2001). It can be found in diverse wooded habitats, including dry and rain forests, secondary forest, savanna woodlands, suburban gardens, and close to tribal and village settlements. It is extremely common on the Loyalty Islands (Barré et al. 2006) and on Pine Island but uncommon on the New Caledonian mainland, where it is restricted to some dry-forest areas or low-elevation woodlands (Barré et al. 2007).

We used a single bird maintained in an aviary to test the effect of gut passage on seed germination. Ripe, dark purple fruits of Diospyros fasciculosa and Vitex cf. collina were randomly collected from trees in a remnant of dry forest located in Pointe Maa, near Nouméa. Ripe fruits of Mimusops elengi were collected from trees in the Malhec dry forest in northern New Caledonia. Fruits were transported to the laboratory using a coolbag to prevent them from drying or fermenting. We immediately measured fruit size (equatorial and polar diameters) and weighed both fruits and seeds, then deducing pulp weight. We calculated the ratio $\mathrm{R}_{\mathrm{p} / \mathrm{f}}$ between the mass of pulp (p) and the mass of the fruit (f) (see Table 1). Birds swallow ovoid fruits with the long axis parallel to the length of the bill, so that the upper size limit of a fruit that can be swallowed is determined by its equatorial diameter (Meehan et al. 2002).

Fruits of each species were prepared in three ways. In Batch A, intact fleshy fruits were put into germination conditions. In Batch B, seeds were manually extracted, rapidly washed, and put into germination conditions. In Batch $\mathrm{C}$, fruits were fed to the captive bird and seeds were collected separately from the droppings, rapidly washed, and put into germination conditions. The seeds were put into germination conditions the same day, as soon as possible after defecation. Seeds in fecal droppings generally occurred in clumps (Hegde et al. 1991). Each treatment (A, B, and C) was replicated four times using 25 seeds, except for ingested seeds of $D$. fasciculosa, which had a sample size of 36 .

Because conditions in growth chambers 
TABLE 1

Values of Seed Traits and Seed Retention Time of the Three Species Studied

\begin{tabular}{|c|c|c|c|c|c|c|c|c|c|}
\hline \multirow[b]{2}{*}{ Tree Species } & \multicolumn{5}{|c|}{ Fruit Traits ${ }^{a}$} & \multicolumn{4}{|c|}{$\mathrm{MRT}^{b}(\min )$} \\
\hline & $n_{1}$ & $\mathrm{PD}(\mathrm{mm})$ & $\mathrm{ED}(\mathrm{mm})$ & Mass (g) & $\mathrm{R}_{\mathrm{p} / \mathrm{f}}$ & $n_{2}$ & Mean \pm SD & Min. & Max. \\
\hline Diospyros fasciculosa & 100 & $14.1 \pm 0.9$ & $11.4 \pm 1.2$ & $1.5 \pm 0.3$ & 0.87 & 75 & $17.4 \pm 2.7$ & 14.0 & 20.50 \\
\hline Mimusops elengi & 100 & $18.6 \pm 0.9$ & $15.7 \pm 0.5$ & $2.6 \pm 0.3$ & 0.80 & 17 & $52.4 \pm 13.1$ & 40.2 & 73.6 \\
\hline Vitex cf. collina & 100 & $11.8 \pm 1.2$ & $10.5 \pm 1.2$ & $1.2 \pm 0.2$ & 0.56 & 75 & $27.3 \pm 1.3$ & 25.5 & 29.0 \\
\hline
\end{tabular}

${ }^{a} \mathrm{PD}$, polar diameter; $\mathrm{ED}$, equatorial diameter; $\mathrm{R}_{\mathrm{p} / \mathrm{f}}$, ratio between the mass of pulp and the mass of fruit.

${ }^{b}$ MRT, Mean Retention Time.

are generally favorable, they can obscure significant differences between treatments (Traveset and Verdu 2001). Consequently, batches were monitored in a room where the temperature was close to ambient. Batches were sown on a substrate composed of coconut fibers and were regularly watered. Twice a week, the dishes were examined, and germinated seeds were counted and removed to reduce any possible effect on the remaining ungerminated seeds. Germination was defined as the emergence of the rootlet from the seed or fruit. For the germination response, we considered the germinability, G (defined as the proportion of seeds that germinated during the monitoring period, which was long enough to approximate time to final germination), and the length of dormancy, $\mathrm{T}_{0}$ (defined as the time elapsed from sowing until first germination) (Scott et al. 1984, Traveset and Verdu 2001). We also measured the Minimum Retention Time (MRT) of seeds during gut passage. The bird was offered 12 ripe fruits of one of the plant species plus water ad libitum and the time was recorded. Then, the first appearance of the seeds by defecation was recorded (Barnea et al. 1991). Each treatment was replicated five times. Mann-Whitney and KruskalWallis nonparametric statistical tests were used for comparisons between treatments.

\section{RESULTS}

Fruit measurements are reported in Table 1. Considering the diverse fruit traits, Diospyros fasciculosa tended to have intermediate values, Mimusops elengi showed the highest values, and Vitex cf. collina the smallest ones. No fruit or seed was observed to be regurgitated. Observations during the trial showed that fruits were easily and rapidly ingested.

Seeds were monitored during 269 days (ca. 9 months) for D. fasciculosa, 145 days for M. elengi (ca. 5 months), and 95 days (ca. 3 months) for $V$. cf. collina. The cumulative percentage of seeds germinated is shown in Figure 1.

For D. fasciculosa, gut passage enhanced germinability compared with that of whole fruits $\left(U=0.0, P=.019, \chi^{2}=5.463\right)$ but did not differ significantly from results with the pulp removed by hand $(U=5.0$, $\left.P=.386, \chi^{2}=0.750\right)$. For $M$. elengi, gut passage enhanced germinability compared with that of whole fruits $(U=1.0, P=.043$, $\left.\chi^{2}=4.083\right)$ but not compared with seeds whose pulp was removed $(U=7.5, P=.882$, $\left.\chi^{2}=0.022\right)$. For $V$. cf. collina, gut passage did not enhance germinability compared with that of whole fruits or pulp removal (same statistical values: $U=12.5, P=.180$, $\left.\chi^{2}=1.794\right)$. Length of dormancy $\mathrm{T}_{0}$ did not differ among fruit treatments for any species (D. fasciculosa: $\mathrm{T}_{0}=182 \pm 19$ days; M. elengi: $\mathrm{T}_{0}=38 \pm 11$ days; $V$. cf. collina: $\mathrm{T}_{0}=26 \pm 4$ days).

Data on MRT are given in Table 1. MRT differs significantly among the three species $(K=42.1, P<.001)$. MRT was significantly higher for $M$. elengi $(M R T=52.4 \mathrm{~min})$ than for D. fasciculosa (MRT $=17.4 \mathrm{~min}$, $K=33.9, \quad P<.001)$ and $V$. cf. collina $(\mathrm{MRT}=27.3$ min, $K=30.8, \quad P<.001)$. Moreover, MRT was higher for $V$. cf. collina than for D. fasciculosa $(K=7.6, P=.006)$. 
(a)

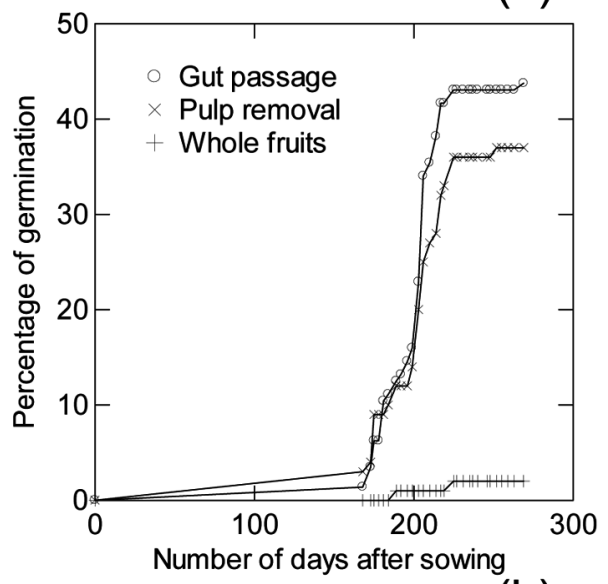

(b)

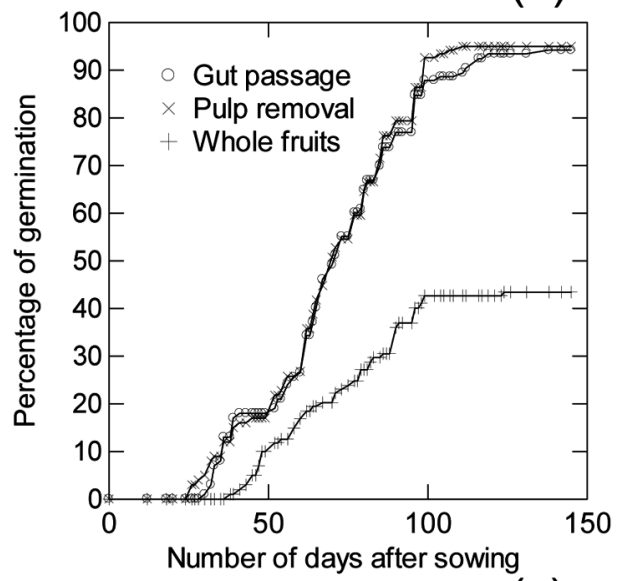

(c)

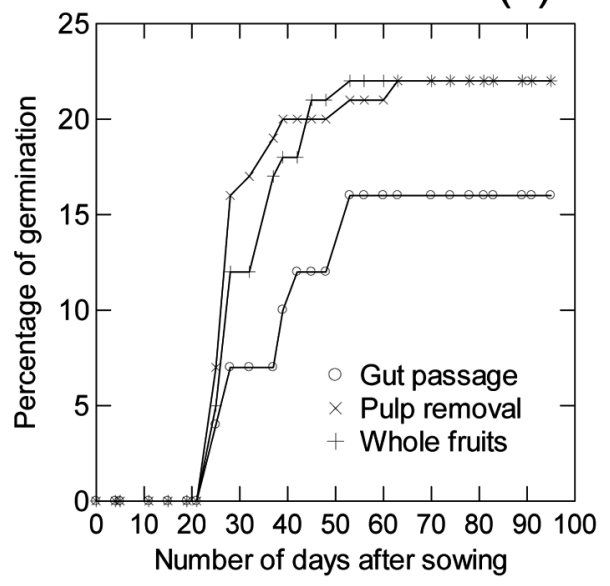

DISCUSSION

The rather small size of seeds was probably responsible for the absence of regurgitation. Small seeds, which are retained longer, are more likely to be dispersed on long distances by birds than large ones, which are regurgitated (Hegde et al. 1991). For D. fasciculosa and $M$. elengi, gut passage resulted in a simple pulp removal effect; further facilitation of germination due to scarification of the seed coat was not observed. For $V$. cf. collina, the absence of effect from gut passage can be explained by the absence of inhibition from pulp, which was also supported by the lack of effect of artificial pulp removal, compared with whole fruits. Moreover, no scarification effect was noted. The inhibition effect of pulp observed in D. fasciculosa and M. elengi may be related to their pulp compositions. A high sugar content in the pulp of mature fruits induces a high osmotic pressure, which may inhibit germination (Samuels and Levey 2005). The sugar content of the pulp of $D$. fasciculosa and of $M$. elengi is higher than that of $V$. cf. collina. (Boissenin et al. 2006).

Our results are consistent with previous reviews on the effect on germination of seed passage through vertebrate frugivore guts, showing that the enhancement of germination is commonly caused mostly by pulp removal rather than by scarification (Robertson et al. 2006).

Unlike the situation with the clovenfeathered dove Drepanoptila bolosericea Temminck and sandalwood, in which seeds were abraded during gut passage, shortening the length of dormancy (Tassin et al. 2008), gut passage did not shorten the duration of seed dormancy in any of the tree species we studied. This result is consistent with the evidence of a simple pulp deinhibition effect for D. fasciculosa and M. elengi. More rapid germination can be either beneficial or detrimental, depending on the ecological conditions pre-

FIgURE 1. Variation in percentage seed germination with the number of days after sowing of (a) Diospyros fasciculosa, (b) Mimusops elengi, and (c) Vitex cf. collina, comparing three treatments: digestion of fruits (gut passage) by Ptilinopus greyii, pulp removed (seeds only), and whole fruits. 
vailing in the habitat (Kelly et al. 2004, Peco et al. 2006). For D. fasciculosa, about 6 months of dormancy is necessary to ensure that germination occurs during the humid season, because fruit maturation peaks at the beginning of the dry season (C. Chambrey, unpubl. data). Shortening this delay would likely reduce seedling establishment in this species and not enhance regeneration.

We provide evidence for the potential role of Ptilinopus greyii in the dispersal of fleshyfruited dry-forest species: seed germination is enhanced for two (D. fasciculosa and $M$. elengi) of the three tree species, but seed movement is assured for the three species. Considering data gathered on other Ptilinopus species (Brooke and Jones 1995, Stedman and Freifeld 1999), we assume that $P$. greyii can easily disperse seeds from fruits with a diameter of up to $20 \mathrm{~mm}$, and the results obtained with $M$. elengi suggest that some larger fruits can also be dispersed. Thirty-three $(85 \%)$ of 39 fleshy-fruited dry-forest species studied previously on New Caledonia met the size criterion (Boissenin et al. 2006).

Additional research on bird movements and the distances that seeds can travel during gut passage would be of interest. The mean visit length of $P$. greyii foraging in a dry forest tree is $4.1 \mathrm{~min}$ (Boissenin et al. 2006), which is far less than the MRT. Moreover, the redbilled fruit-dove is a rapid flyer (N.B., pers. obs.). Thus, it is likely that it carries seeds over long distances including between islands, at least occasionally.

\section{ACKNOWLEDGMENTS}

We thank Alexandre Bouarat for germination monitoring. We also gratefully thank two anonymous reviewers for critical constructive comments.

\section{Literature Cited}

Agami, M., and Y. Waisel. 1986. The role of mallard ducks (Anas platyrbynchos) in the distribution and germination of seeds of the submerged hydrophyte Najas marina L. Oecologia (Berl.) 68:473-475.
Barnea, A., Y. Yom-Tov, and J. Friedman. 1991. Does ingestion by birds affect seed germination? Funct. Ecol. 5:394-402.

Barré, N., J. Baudat-Franceschi, J. Spaggiari, V. Chartendrault, P. Bachy, F. Desmoulins, and J. Guhring. 2007. Second complément à la liste des oiseaux de NouvelleCalédonie. Alauda 75:129-144.

Barré, N., P. Villard, N. Manceau, L. Monimeau, and C. Menard. 2006. Les oiseaux de l'archipel des Loyauté (NouvelleCalédonie): Inventaire et éléments d'écologie et de biogéographie. Rev. Ecol. Terre Vie 61:175-194.

Boissenin, M., S. Gomez, N. Barré, C. Chambrey, and J. Tassin. 2006. Interactions entre l'avifaune frugivore et la flore ligneuse en forêt sèche de NouvelleCalédonie. Research report 3/2006. IAC, Dry Forest Programme, Noumea, New Caledonia.

Brooke, M., and P. J. Jones. 1995. The diet of the Henderson fruit dove Ptilinopus insularis. I. Field observations of fruit choice. Biol. J. Linn. Soc. 56:149-165.

Brown, E. D., and M. J. G. Hopkins. 2002. Tests of disperser specificity between frugivorous birds and rainforest fruits in New Guinea. Emu 102:137-146.

Carlquist, S. 1996. Plant dispersal and the origin of Pacific island floras. Pages 153-164 in A. Keast and S. E. Miller, eds. The origin and evolution of Pacific island biotas, New Guinea to eastern Polynesia: Patterns and processes. SPB Academic Publishing, Amsterdam.

Cox, P. A., T. Elmqvist, E. D. Pierson, and W. E. Rainey. 1991. Flying foxes as strong interactors in South Pacific islands ecosystems: A conservation hypothesis. Conserv. Biol. 5:448-454.

Gibbs, D., E. Barnes, and J. Cox. 2001. Pigeons and doves: A guide to the pigeons and doves of the world. Pica Press, Robertsbridge, United Kingdom.

Gillespie, T. W., and T. Jaffré. 2003. Tropical dry forests in New Caledonia. Biodivers. Conserv. 12:1687-1697.

Harbaugh, D. T., and B. G. Baldwin. 2007. Phylogeny and biogeography of the sandalwoods (Santalum, Santalaceae): Re- 
peated dispersals throughout the Pacific. Am. J. Bot. 94:1028-1040.

Hegde, S. G., R. U. Shaanker, and K. N. Ganeshaiah. 1991. Evolution of seed size in the bird-dispersed tree Santalum album L.: A trade off between seedling establishment and dispersal efficiency. Evol. Trends Plants 5:131-135.

Janzen, D. H. 2002. Tropical dry forest: Area de conservation Guanacaste, northwestern Costa Rica. Pages 559-583 in M. R. Perrow and A. J. Davy, eds. Handbook of ecological restoration. Vol. 2, Restoration in practice. Cambridge University Press, Cambridge.

Kelly, D., J. J. Ladley, and A. W. Robertson. 2004. Is dispersal easier than pollination? Two tests in New Zealand Loranthaceae. N. Z. J. Bot. 42:89-103.

Mayer, A. M., and A. Poljakoff-Mayber. 1982. The germination of seeds. 3rd ed. Pergamon Press, Oxford.

McConkey, K. R., H. J. Meehan, and D. R. Drake. 2004. Seed dispersal by Pacific Pigeons (Ducula pacifica) in Tonga, western Polynesia. Emu 104:369-376.

Meehan, H. J., K. R. McConkey, and D. R. Drake. 2002. Potential disruptions to seed dispersal mutualisms in Tonga, western Polynesia. J. Biogeogr. 29:695-712.

Peco, B., L. Lopez-Merino, and M. Alvir. 2006. Survival and germination of Mediterranean grassland species after simulated sheep ingestion: Ecological correlates with seed traits. Acta Oecol. 30:269-275.

Robertson, A. W., A. Trass, J. J. Ladley, and D. Kelly. 2006. Assessing the benefits of frugivory for seed germination: The importance of deinhibition effect. Funct. Ecol. 20:58-66.
Samuels, I. A., and D. J. Levey. 2005. Effects of gut passage on seed germination: Do experiments answer the questions they ask? Funct. Ecol. 19:365-368.

Scott, S. J., R. A. Jones, and W. A. Williams. 1984. Review of data analysis methods for seed germination. Crop Sci. 24:11921199.

Steadman, D. W., and H. B. Freifeld. 1999. The food habits of Polynesian pigeons and doves: A systematic and biogeographic review. Ecotropica (Bonn) 5:13-33.

Tassin, J., N. Barré, and J.-M. Bouvet. 2008. Effect of ingestion by Drepanoptila holosericea (Columbidae) on the seed germination of Santalum austrocaledonicum (Santalaceae). J. Trop. Ecol. 24:215-218.

Traveset, A., A. W. Robertson, and J. Rodriguez-Perez. 2007. A review of the role of endozoochory on seed germination. Pages 78-103 in A. J. Dennis, R. Green, E. W. Schupp, and D. A. Westcott, eds. Seed dispersal theory and its application in a changing world. CABI Publishing, Wallingford, United Kingdom.

Traveset, A., and M. Verdu. 2001. A metaanalysis of gut treatment on seed germination. Pages 339-350 in D. Levey, M. Galetti and W. Silva, eds. Frugivores and seed dispersal: Ecology, evolution and conservation. CABI International, Wallingford, United Kingdom.

Van der Pijl, L. 1982. Principles of dispersal in higher plants. Springer, New York.

Willson, M. F., and A. Traveset. 2000. The ecology of seed dispersal. Pages 85-110 in M. Fenner, ed. Seeds: The ecology of regeneration of plant communities. CABI Publishing, Wallingford, United Kingdom. 